\title{
Skål i skuret!
}

\section{Sundhed, omsorg og ordentlighed blandt xldre udsatte rusmiddelbrugere}

\author{
Jonas Strandholdt Bach ${ }^{1}$ \\ Bagga Bjerge $^{2}$
}

${ }^{1}$ Center for Rusmiddelforskning, Aarhus Universitet jsb.crf@psy.au.dk

2 Center for Rusmiddelforskning, Aarhus Universitet

Bach, Jonas Strandholdt \& Bjerge, Bagga. (2021). Skål i skuret! Sundhed, omsorg og ordentlighed blandt ældre udsatte rugsmiddelbrugere. Tidsskrift for Forskning $i$ Sygdom og Samfund, nr. 35, 139-158

Borgere med et stort forbrug af rusmidler er markant overrepræsenterede pa parametre for udsathed som for eksempel manglende tilknytning til arbejdsmarkedet, hjemløshed og ensomhed, og deres sundhedstilstand er dårligere end gennemsnittet. En gruppe, som er særligt udsatte blandt rusmiddelbrugere, er de ældre eller alderssvakkede brugere. Denne artikel fokuserer på en gruppe xldre rusmiddelbrugeres udfordringer i møderne med velfærds- og sundhedssystem, blandt andet bureaukratiske barrierer, manglende forståelse fra professionelle og frygten for at miste autonomi. At de oplever moderne med systemerne som problematisk, betyder dog ikke, at de ikke forsøger at agere "rigtigt" $i$ forhold til sundhedsmæssige udfordringer. Med udgangspunkt i samværet omkring et drikkeskur forsøger brugerne selv at tage ansvar for egen sundhed og samtidig at agere omsorgspersoner for andre brugere. Fællesskabet er, selv om det er baseret på "kassérbare relationer" (Desmond, 2012), centralt for brugernes trivsel og sundhed. Artiklen argumenterer for, at brugerne efter bedste evne og under egne vilkår agerer efter sundhedsmæssige retningslinier - for eksempel $i$ forbindelse med corona-pandemien - og de bestræber sig pa at opfore sig som "ordentlige" medborgere. Artiklen argumenterer endvidere for, at det er vigtigt at inddrage erfaringer fra udsatte borgere for bedre at kunne rumme dem i velfards-og sundhedstilbud, 
hvor de ellers kan have svært ved at passe ind. Artiklen er baseret på data indsamlet via etnografisk feltarbejde i en forstad til Aarhus i 2019-20.

\section{Cheers in the shed! Health, care and decency among ageing marginalized drug- and alcohol users}

Citizens who consume large amounts of alcohol and drugs are overrepresented in statistics on vulnerability such as unemployment, homelessness and loneliness and their general health conditions are below the average of the general population. Particularly vulnerable are the old and aging users of drugs and alcohol. This article focuses on a group of aging drug and alcohol users' challenges in relation to the welfare and health systems, including bureaucratic barriers, lack of understanding from professionals and the fear of losing personal autonomy. Even though they experience interactions with the systems as problematic, it does not entail that they do not attempt to follow official health guidelines, and when exploring the small community of drug and alcohol users in the drinking shed, it becomes evident that the users attempt to take care of themselves as well as others. The article argues that the users, by their own best accord, act in accordance with health guidelines, for example during the Covid-19 pandemic, and they try to act as "decent" citizens. It is furthermore argued that the experiences of vulnerable citizens could be advantageously included in welfare and health efforts, where alcohol and drug users might have trouble fitting in. The article is based on ethnographic fieldwork conducted in a suburb of the Danish city, Aarhus, in 2019 and 2020.

\section{Indledning}

Borgere med et stort forbrug af rusmidler har en markant dårligere sundhedstilstand end gennemsnittet af danskere i forhold til fysisk såvel som mental sygelighed, og de dør markant tidligere end resten af befolkningen (Sundhedsstyrelsen, 2012; Ahlmark et al., 2017; Pedersen, 2018; Møller \& Merrild, 2019). De er også overrepræsenterede på parametre for udsathed som for eksempel manglende tilknytning til arbejdsmarkedet, hjemløshed og ensomhed (Benjaminsen, 2019). En gruppe, som er særligt udsatte ${ }^{i}$ blandt rusmiddelbrugere, er de ældre og alderssvækkede rusmiddelbrugere (Sundhedsstyrelsen, 2020; Rambøll, 2020, Pedersen, 2018): Det vil sige en gruppe af borgere, der på papiret måske kun er midaldrende (45-60 år), men som allerede er så svækkede både kognitivt og fysisk grundet rus- 
middelbrug og et hårdt liv, at deres sundhedsmæssige udfordringer og alder svarer til ældre og gamle (60+ år) gennemsnitsborgere (se Sundhedssyrelsen, 2020). Vi anvender i artiklen derfor, jævnfør Rambøll's rapport for Sundhedsstyrelsen (2020), en bred definition af ældre eller alderssvækkede, da aldersvækkelse - både kognitiv og fysisk - ofte indtræffer tidligere blandt rusmiddelbrugere end for den øvrige befolkning.

I takt med at den generelle befolkning oplever en stigende levealder, stiger antallet af ældre udsatte rusmiddelbrugere, hvilket blandet andet kan tilskrives skadesreducerende tiltag som stofindtagelsesrum og socialsygeplejerskers arbejde på sygehuse, samt kommunale forebyggende indsatser. De ældre og aldersvækkede rusmiddelbrugeres problemstillinger er oftest sammensatte og komplekse, og deres hverdag er ofte mere kaotisk end andre ældre borgeres. De er ofte svære at opnå kontakt til og fastholde i eksempelvis sundhedsindsatser, og mange sundhedsprofessionelle mangler erfaring med og kendskab til gruppen. Samtidig har rusmiddelbrugere ofte lav tillid til velfærdssystemet ${ }^{\mathrm{ti}}$ grundet dårlige erfaringer, og de søger ofte i videst mulige omfang at undgå "systemet" (Brandt et al., 2009; Pedersen, 2009; Rasmussen, 2019).

Viden, data og forskning om ældre og alderssvækkede rusmiddelbrugere er imidlertid sparsom. Der findes enkelte rapporter, som direkte eller indirekte dokumenterer den sundhedsmæssige og sociale status for gruppen (Rambøll, 2020; Benjaminsen, 2019; Ahlmark et al., 2017), og der eksisterer få kvalitative undersøgelser, som dog enten ikke har et specifikt fokus på sundhed (fx Rasmussen, 2019) eller aldring og alderssvækkelse (fx Pedersen, 2009; Brandt, 2009). Med udgangspunkt i en kvalitativ undersøgelse af udsatte ældre og alderssvækkede rusmiddelbrugeres fællesskab i og omkring et (drikke)skur ${ }^{\mathrm{iii}} \mathrm{i}$ en forstad til Aarhus analyserer og diskuterer vi skurets brugeres relationer til social- og sundhedssystemet, det sociale fællesskab og den omsorg rusmiddelbrugerne drager for sig selv og hinanden med henblik på at klare sig økonomisk, trivsels- og sundhedsmæssigt. Artiklen beskriver dels skurets brugeres problemstillinger og daglige omgang $\mathrm{i}$ skuret, dels deres tidligere erfaringer og aktuelle brug af sundhedssystemets tilbud eller mangel på samme. Artiklen viser endvidere, hvordan skurets brugere på egen hånd søger at håndtere sundhedsmæssige og andre udfordringer, og hvordan de formår at løse flere af disse udfordringer på en, for dem, hensigtsmæssig måde. Gensidig omsorg for hinanden spiller en central rolle for skurets brugeres fysiske og psykiske velbefindende. Denne omsorg har en særlig karakter, idet den jævnligt udfordres, for eksempel hvis nogle brugere opfører sig dårligt over for de andre, eller hvis behovet for penge til at betale for alkohol og stoffer påvirker 
de venskabelige relationer negativt. Det at drage omsorg for andre, som man har opbygget relationer til i skuret, italesættes også af brugerne som en del af at opføre sig "ordentligt", og netop det at opføre sig som et "ordentligt" menneske, fremstår centralt for skurets brugere. Endvidere diskuterer vi, hvordan brugernes erfaringer kan inddrages i forhold til at mindske de udfordringer, som brugere og professionelle oplever i mødet omkring indsatser og behandlinger. Analytisk trækker artiklen på to perspektiver, der bidrager til forståelse af de ældre og alderssvækkede udsatte borgere; dels de organisatoriske barrierer for hjælp i velfærdsstaten, dels brugernes indbyrdes "kassérbare relationer" og spilleregler for fællesskabet.

\section{Kontekst og metode: Skuret i Kildebjerg}

Artiklen bygger på data indsamlet omkring et drikkeskur ved et mindre torv i en forstad til Aarhus, hvor en gruppe overvejende ældre rusmiddelbrugere dagligt mødes. Data er baseret på etnografisk feltarbejde i form af deltagerobservation udført mellem september 2019 og november 2020 samt kvalitative interviews udført i juni, juli og oktober 2020. Skuret er besøgt en til to gange ugentligt året rundt, bortset fra sommerferieperioden og nedlukningsperioder på grund af Covid-19. Besøgene har haft en varighed på mellem en og fem timer - gennemsnitligt omkring tre timer.

Brugerne og lokalområdet, som her kaldes Kildebjerg, er anonymiserede. Feltarbejde og interviews er udført af artiklens ene forfatter og bestod i at opsøge og "hænge ud" i skuret, lytte og tale med skurets brugere om, hvad der optog dem, og blive ved med at vende tilbage for at opbygge tillid samt notere temaer. Disse blev udforsket yderligere i semistrukturerede dybdegående interviews med seks af skurets brugere, hvoraf fire er interviewet over to omgange. Endvidere er en boligsocial medarbejder, som har arbejdet i området i en årrække, interviewet om skurets historie og brugernes rolle i lokalområdet.

Skuret er ca. 5 × 3 meter med bliktag og -vægge fæstnet til stålstolper. Der er vægge på to en halv side, så der oftest er læ, men når vindretningen står forkert, blæser og regner det ind. På bagsiden af skuret er der et lille pissoir - også overdækket med bliktag og skærmet af så forbipasserende ikke kan kigge ind. I skuret står et par borde og 10-12 stole. I perioder står der også et bord og et par stole lige uden for skuret. Ifølge brugerne, har der eksisteret en form for skur til områdets rusmiddelbrugere ved torvet i Kildebjerg siden 1990'erne. Dengang var det en lokal præst og lederen af den lokale boligsociale indsats, der stod for at tage initiativ 
til at give rusmiddelbrugere hovedsageligt med bopæl i lokalområdet et sted, hvor de kunne sidde skærmet af fra nysgerrige blikke - og hvor forbipasserende ikke blev konfronteret med deres til tider kaotiske adfærdv . Endvidere skulle det også tilskynde brugerne til ikke at hænge ud på trappetrinnene ved den nærliggende kirke eller foran indgangen til det lokale supermarked, hvor de til tider blev oplevet som "utryghedsskabende" , blandt andet fordi der ofte var højlydte skænderier og ind i mellem slagsmål. Supermarkedet gik også med i arbejdet med at få bygget et skur. Efter et første forgæves forsøg, hvor skuret blev placeret i et nærliggende parkområde, fik skuret plads tæt ved den nuværende placering mellem supermarkedet og et byggeri med ungdomsboliger og væk fra indgangen til supermarkedet. Fra skuret kan man følge med i livet i området, hvor folk går og cykler til og fra supermarked og daginstitutioner, boliger og bibliotek, kirke, moské, kiosk og pizzeria. Skurets brugere kan følge med i, hvem der parkerer på parkeringspladsen, og ofte udveksles der hilsener og småsnakkes med forbipasserende.

Feltarbejdet havde indledende fokus på brugernes og skurets placering i byrummet, men i løbet af feltarbejdet skiftede fokus til også at omhandle brugernes oplevelser af møder med social- og sundhedssystemet, deres forhold til pårørende, naboer, professionelle og andre i lokalområdet, og omsorg, disciplinering og selvdisciplinering blandt brugerne. I feltarbejdsperioden var der kontakt til ca. 35 brugere, som enten kom ofte eller mere sporadisk og 'hang ud' i skuret i kortere eller længere tid. Omkring 2/3 af skurets brugere var mænd. Langt de fleste havde et dagligt forbrug eller overforbrug af alkohol og i nogles tilfælde også andre rusmidler - herunder cannabis og heroin. Enkelte var aldersmæssigt i 40'erne, de fleste i 50'erne og enkelte i 60'erne. De fleste var på førtidspension grundet rusmiddelbrugs- og helbredsproblematikker. Generelt var det kun alkohol, der blev indtaget i skuret, selv om der indimellem blev røget cannabis enten i skuret eller lige udenfor. 


\section{Analytisk ramme: Organisatoriske barrierer og udsatte brugeres fællesskaber}

\section{Organisatoriske barrierer}

Det er velkendt, at borgere med komplekse sundheds- og sociale problemstillinger er vanskelige at håndtere i de etablerede velfærdssystemer (Bjerge et al., 2020; Bjerge et al., 2019; Bjerge \& Houborg, 2019; Nygaard-Christensen et al., 2018; Social- og Indenrigsministeriet, 2016; Andersen \& Bengtsson, 2019; Møller \& Merrild, 2019; Merrild \& Jönsson, 2019). Borgerne kan være vanskelige at etablere kontakt til, og grundet deres kaotiske livsførelse kan de være vanskelige at rumme i diverse systemer for sagsbehandlere, sygeplejersker og andet frontpersonale. Endvidere fokuserer ikke mindst sundhedssystemet oftest på én problemstilling ad gangen (Bjerge et al., 2020; Bjerge et al., 2019; Møller \& Merrild, 2019). For eksempel skal borgere hos den praktiserende læge (i hvert tilfælde ifølge officielle retningslinjer) bestille separate konsultationstider til separate problemstillinger. Et andet velbeskrevet eksempel er, at stofbrugere med psykiatriske problemstillinger ofte har haft oplevelsen af at blive afvist i psykiatrien, fordi de skal ophøre med deres stofindtag før psykiatrisk udredning og behandling kan iværksættes - og at stofbehandlingen har haft vanskeligt ved at håndtere brugere med psykiske problemstillinger (Bjerge et al., 2019; Johansen \& Larsen, 2019; Thylstrup \& Hesse, 2019; Frederiksen, Jones \& Pedersen, 2019). Med andre ord, så opererer velfærdssystemet ofte med, at den grundlæggende problemstilling skal identificeres, og så kan andre typer indsatser efterfølgende iværksættes og herigennem bedre borgerens sundhedsmæssige, økonomiske eller sociale situation. En given problemstilling risikerer at blive isoleret som et enkeltstående fænomen, og man har derfor ikke nødvendigvis blik for andre faktorer, der kan påvirke borgerens samlede situation (Bjerge et al., 2019; Bjerge et al., 2020; Møller \& Merrild, 2019). Dog har der i de senere år både politisk og i praksis været stor bevågenhed i forhold til udfordringerne med de komplekse borgersager (Sundhedsstyrelsen, 2012; Social- og Indenrigsministeriet, 2016; Rambøll, 2020; Bjerge et al., 2019; Pedersen, 2018), og i indsatser rettet mod rusmiddelbrugere tales der politisk og i feltet om nødvendigheden af "tværsektorielle samarbejder", koordinering", "helhedsorientering" og "borgerstyrede forløb". Der findes også eksempler på, at dette lykkes i praksis for eksempel med socialsygeplejersker. Dog beror mange af disse eksempler på, at nogle medarbejdere "går en ekstra mil", eksperimenterer med nye 
måder at arbejde på, og at indsatserne derfor ofte er meget personbårne (af de professionelle) end at de beror på egentlige organisatoriske forandringer (Bjerge et al., 2019). Medarbejderne oplever ofte, at dette er nødvendigt for at kunne hjælpe udsatte borgere, men det gør også indsatserne sårbare i forhold til forandringer, udskiftning af personale etc. Det generelle billede viser, at de måder, hvorpå der i velfærdssystemet tilrettelægges services og tilbud, ofte ikke matcher brugernes reelle muligheder for deltagelse. Endvidere præges velfærdssystemet i stor udstrækning stadig ofte af kasse- og silotænkning og mangler koordinering (Bjerge et al., 2019; Bjerge et al., 2018). Endelig kan det opleves som forvirrende og utrygt for brugerne, når der ikke er kontinuitet i relationerne til systemernes ansatte, for eksempel når de mødes af forskellige og skiftende professionelles holdninger og forslag til løsninger på deres problemstillinger (ibid.).

\section{Kassérbare relationer}

For skurets brugere er det ofte vanskeligt at benytte velfærdssystemet. Derfor inddrager vi også et analytisk perspektiv til at forstå, hvad brugerne så gør i stedet i dagligdagen, når de har brug for hjælp. Dette perspektiv er inspireret af studier og konceptualiseringer af indbyrdes relationer mellem forskellige typer af udsatte mennesker (Bourgois \& Schonberg, 2009; Desmond, 2012; Mortensen, 2019). Studierne viser, hvordan borgere i udsatte boligområder fx i USA er afhængige af "disposable ties" - kassérbare relationer - for at kunne klare sig i dagligdagen (Desmond, 2012: 1295). Kassérbare relationer står i modsætning til familiebånd, fordi de ofte knyttes til mere eller mindre fremmede og ofte brydes hurtigt igen, når man ikke længere har brug for relationen, eller fordi man mister kontakten. Udsatte borgere finder ofte sammen i kammeratskaber, hvor solidaritet og potentialet for svigt eksisterer side om side (se for eksempel Bourgois \& Schonberg, 2009; Rasmussen, 2019). I disse fællesskaber er mistillid ofte en del af omgangsformen, og man fortæller ikke hinanden alt eller undgår at invitere hinanden indenfor i de mest personlige rum - risikoen for at nogen potentielt kan misbruge denne tillid er for stor (Mortensen, 2019). Alligevel viser studierne, hvordan disse typer af relationer er centrale for parterne i relationen. Udsatte menneskers indbyrdes relationer bygger ofte både på vagtsomhed og er opstået af at være i samme båd. Fællesskaberne giver brugerne muligheder for hjælp, som de ellers ville have været foruden. Disse indsigter fra litteraturen resonerer med de indsamlede data fra skuret. 
I analysen af udsattes fællesskaber opererer Bourgois \& Schonberg (2009) endvidere med begrebet "gray zone" (fra Walther Benjamin), på dansk gråzone, til at beskrive, hvordan hjemløse i Los Angeles, USA lever under nogle andre regler end gennemsnitsborgeren - de bebor "a morally ambiguous space" (ibid.: X). De hjemløse agerer både "moralsk" og har agens, men deres ageren udspiller sig ofte på en anden baggrund end for de fleste andre mennesker, som har andre rammer omkring deres tilværelse. For eksempel spiller fysisk afhængighed, samt økonomiske og sociale begrænsninger en væsentlig rolle i forhold til at begrænse deres agens eller forme den i bestemte retninger (ibid.). Selv om brugerne af skuret i Kildebjerg relativt set er mindre udsatte end de overvejende hjemløse heroinbrugere, som Bourgois \& Schonberg beskriver, er der alligevel ligheder i, hvordan de oplever deres plads i og relationer til det omgivende samfund.

På lige fod med andre typer af borgere følger udsatte borgere altså også nogle spilleregler samt bestræber sig på at opføre sig moralsk og "ordentligt". De balancerer mellem på den ene side at kunne klare sig i gademiljøet og anerkende ambivalensen i de relationer, man indgår i. På den anden side bestræber de sig på at tilpasse sig den omgivende verdens forventninger og blik samt at drage omsorg for deres kammerater, når de har brug for hjælp. Endelig er den enkelte gensidigt afhængig af denne type hjælp, fordi det ofte er den eneste tilgængelige.

Møder med "systemet"

Fælles for mange af skurets brugere er, at deres relationer med social- og sundhedssystemet er præget af dårlige oplevelser og mistillid. Flere af brugerne beretter for eksempel om lange, opslidende forløb omkring retten til førtidspension. I løbet af foråret får 55-årige Laurits, en af skurets faste brugere, tilkendt førtidspension, da han vurderes at være fysisk og kognitivt ude af stand til at kunne varetage et arbejde på grund af et langvarigt alkoholmisbrug. Det sker efter et forløb, der ifølge Laurits har varet 6 år og kun er lykkedes, fordi hans bostøtte og hans mentor har talt hans sag. Også 56-årige Britta har en bostøtte, der hjælper med at navigere i velfærdssystemet. Hun er førtidspensionist efter et årelangt pillemisbrug udløst af receptudskrevne benzodiazepiner, som nu er erstattet af et overforbrug af alkohol. Efter eget udsagn bliver hun meget hurtigt vred over, at det er svært at komme igennem til kommunen og andre offentlige institutioner, og hun er derfor ophidset, når hun endelig får en medarbejder i røret. Derfor er bostøtten vigtig for hendes kontakt med velfærdssystemet, og denne er også i færd med at hjælpe hende med at få ordnet sine tænder, som, hun selv beskriver, "ligner en nedbrændt negerlandsby". Hvor de brugere, der har bostøtter tilknyttet, generelt oplever at bostøtterne hjælper med at navigere i velfærdssystemet, oplever skurets 
brugere andre møder mellem dem selv og social- og sundhedssystemet som problematiske eller mangelfulde.

62-årige Karl sidder i kørestol og er en halv time om at komme fra sin seng og over i kørestolen uden hjælp. Han får hjemmehjælp i sin bolig, men ofte kommer hjælperne så sent på morgenen, at Karl er stået op selv, kravlet op i sin kørestol og er kørt op til skuret, før de er dukket op. Ofte har han en flaske med sig, som han kan tisse i. Én gang, da han vil tisse i flasken, får han fingrene ned i sin ble, der er fyldt med afføring, hvorefter han konstaterer, at han er nødt til at køre hjem og ringe efter hjemmeplejen- "ellers bliver den først skiftet kl. 6 i aften". En dag fortæller Karl, at kommunen gerne vil sende ham til en samtale, hvor de skal "vurdere, hvad han kan". Det vil han ikke, da han frygter, at de vil sende ham først på afvænning og derefter på plejehjem, hvilket vil fjerne ham fra hans netværk i området og i særdeleshed i skuret.

Jakob på 59 har en forhistorie som afhængig af heroin. Han har en alvorlig ryglidelse, som giver ham konstante smerter og sammen med hans stofbrug har udløst førtidspension. Men hans egen læge vil ikke udskrive større doser end 10 mg contalgin ${ }^{v i}$ på grund af hans historik med stofbrug. Det rækker ikke til at dulme smerterne, og han selvmedicinerer derfor med heroin, når han har råd til det, og ellers diverse receptpligtige morfinpræparater købt på det sorte marked. Hvis pengene er få, dulmes smerterne med årgangsøl. Han føler sig stemplet af lægen og uretfærdigt behandlet, fordi det betyder, at han ofte må udholde smerterne, der virker invaliderende og begrænser hans mobilitet og aktivitetsniveau.

De beskrevne eksempler viser, at skurets brugere ofte oplever sig glemt, afvist, mødt med manglende forståelse eller på andre måder dårligt behandlet i sundheds- og velfærdssystemet (Bjerge et al., 2019; Bjerge \& Houborg, 2019; Andersen \& Bengtsson, 2019; Møller \& Merrild, 2019; Merrild \& Jönsson, 2019). De spejler de erfaringer, som andre udsatte borgere - og i særdeleshed udsatte ældre borgere oplever (Sundhedsstyrelsen, 2011; Rambøll, 2020, Social- og Indenrigsministeriet, 2016; Brandt et al., 2009; Pedersen, 2009; Rasmussen, 2019). På trods af øget politisk fokus på udsatte borgere med komplekse problemstillinger oplever de udsatte borgere ikke, at det har en reel betydning for deres hverdag. Ofte er de positive oplevelser begrænset til enkeltpersoner i velfærdssystemet (eksempelvis bostøtter), som gør en ekstra indsats for brugerne og kan skyde genveje i velfærdssystemet, som brugerne ikke selv har adgang til (Bjerge et al., 2019). Det er således ikke velfærdssystemet i sig selv, der formår at rumme og hjælpe brugerne, men derimod professionelle, der går ind i den enkeltes sag og tager den lange, seje kamp på vegne af brugerne. 
Ofte oplever brugerne, at de i høj grad er overladt til sig selv og vælger enten andre løsninger, som Jakob, der finder andre måder at medicinere sig selv på, eller de udskyder at opsøge hjælp til sidste øjeblik, når smerter bliver uudholdelige eller mobiliteten begrænses alvorligt. Som eksemplet med Karl viser, er nogle af brugerne bange for at blive umyndiggjort i systemet og miste deres autonomi og adgangen til deres netværk. Ifølge en anden af skurets brugere, har Karl forsøgt selvmord for at slippe væk fra den voksende trussel om at ende på afvænning og plejehjem. At ende på plejehjem er for flere af brugerne noget nær det værste, de kan forestille sig - og værre end at stille træskoene. De tilbud, som stilles til rådighed af velfærdssystemerne, matcher ofte brugernes ønsker og erfaringer så dårligt, at brugerne fravælger de sundhedsfremmende tiltag, som de potentielt ville kunne profitere af (cf. Møller \& Merrild, 2019; Broholm-Jørgensen et al., 2019). Afstanden mellem brugernes perspektiver på egen livssituation og de repræsentationer af udsatte, ældre borgere, de mødes med i velfærdssystemet, opleves simpelthen som for stor.

\section{Skuret som surrogatfamilie og holdepunkt i tilværelsen}

Det er et fællestræk for skurets brugere, at de har ingen eller meget begrænset, og ofte konfliktfyldt, kontakt med deres nærmeste familie - forældre (hvis de fortsat lever), søskende, tidligere partnere og voksne børn. Familierelationerne er således ofte endnu mere porøse og sårbare end de kassérbare relationer til andre brugere. Det efterlader dem ofte alene i mødet med velfærdssystemet. Det stiller også spørgsmålet om, hvad brugerne så stiller op, når de har brug for hjælp.

Fællesskabet omkring skuret fungerer ofte som en ressource, hvor brugerne har mulighed for at diskutere rimeligheden i reaktionerne fra sagsbehandlere og sundhedspersonale og få luft for utilfredsheden, når de føler sig dårligt behandlet. Samtidig er skuret også omdrejningspunkt for sociale udvekslinger og udtryk for omsorg, som brugerne har svært ved at finde andre steder (jf. Bourgois \& Schonberg, 2009; Desmond, 2012).

For de faste brugere af skuret er det en del af den daglige rytme at lægge vejen forbi. Nogle har faste "mødetider", mens andre dukker op, når det passer ind i dagens program. Skuret er både et geografisk og et temporalt omdrejningspunkt og et holdepunkt i tilværelsen. For Laurits er det et sted, der står i kontrast til de mere 
kaotiske steder han kommer i midtbyen, og også for Jakob, der har frekventeret Aarhus midtbys hårdere miljøer, er forskellen tydelig: "Dernede skal du nok være lidt mere hårdfør for at kunne klare dig". Netop det hårde liv på gaden har flere af skurets brugere lagt bag sig, fordi de nu fysisk har sværere ved at klare sig både i konfrontationer med andre, men også i forhold til at kunne holde til at sove udendørs og indtage større mængder alkohol og stoffer (cf. Rambøll, 2020; Pedersen, 2018; Ahlmark et al., 2017).

For flere er skuret deres primære sociale kontaktpunkt. Langt de fleste, der slår sig ned, kender hinanden, men som Britta fortæller, "90 \% af dem, der kommer her, dem møder jeg kun her". Hun fortæller videre, at hun har været hjemme ved nogen af de andre "for at drikke og ryge den fede", men at hun er påpasselig med, hvem hun inviterer hjem til sig selv: "Jeg synes, jeg har et pænt hjem, jeg vil ikke have nogen med hjem, som kan finde på at pisse i min sofa", fortæller hun. Skuret er på den måde neutral grund, hvor man kan have en relation, hygge sig og snakke sammen, men uden det bliver for forpligtende.

Anette, 59, har boet i området i over 30 år og er en af dem, som er kommet længst tid i skuret. Hun fortæller, hvordan en af de "gamle", der havde noget at skulle have sagt, da hun begyndte at hænge ud her, "lærte os, at når der var begravelse i kirken, så var der ikke én af os, der stod med en bajer i hånden, og vi stod alle sammen stille og ventede på, at kisten var kommet ind i bilen". Siden begyndelsen af 90'erne er mange af "de gamle" faldet fra, og nye er kommet til. Kernen af brugere af skuret er dog stadig folk, der bor i området og har boet der i længere tid. Britta, som er kommet i skuret i 4-5 år, fortæller, hvordan hun stadig føler sig som "ny i klassen" ind i mellem.

"Hvis man spørger pænt og opfører sig ordentligt, så er man velkommen," fik antropologen at vide, første gang han bankede på ydervæggen i skuret og fortalte om forskningsprojektet ${ }^{\mathrm{vii}}$ og spurgte, om han måtte sætte sig. Det er i det store hele tilfældet, selv om der tydeligvis også er uskrevne regler i forhold til hvem, der rent faktisk kommer og sætter sig, og hvordan de bliver taget imod.

Flere af skurets brugere har umiddelbart tillidsfulde relationer til hverandre. Jakob med de konstante rygsmerter har givet Anette sit hævekort, og hun sørger for at handle madvarer og andet han har brug for og styrer hans forbrug. "Så det fungerer sgu meget godt," brummer Jakob, "og det bliver det sikkert ved med". Der er dog en gennemgående påpasselighed i relationerne, som ofte stammer fra dårlige oplevelser med andre i stof- og alkoholmiljøerne. De fleste har oplevet at få stjålet penge, værdigenstande, stoffer derhjemme, og de har lånt penge ud, som de aldrig fik igen, og at man hurtigt kan blive uvenner. 
Alligevel er relationerne i skuret de tætteste relationer, som flere af brugerne har. Britta fortæller: "Jeg sidder her lige så meget, fordi jeg ingen relationer har. Jeg er et ensomt menneske. Hvis jeg ikke sidder her, så ville jeg sidde derhjemme og tale med tv'et. [...]. Jeg har skuret.".

Flere af skurets brugere fortæller om at være blevet smidt ud hjemmefra som teenagere, om brud med kærester og ægtefæller, og børn der enten ikke ønsker at have kontakt eller kun ønsker begrænset kontakt med dem. Skuret er den primære kontakt med andre mennesker. Det er her, de kan vende deres problemer med andre, få gode råd og moralsk opbakning. Der foregår også en cirkulation af ydelser og varer, blandt andet bliver et tv solgt fra en bruger til en anden, og folk fortæller, at de hjælper hinanden med at flytte møbler og lignende. Oftest er ydelsen dog forbundet med en modydelse: Hvis man har fået hjælp er det velset, at man i hvert fald giver noget at drikke, og i nogle situationer forventes der kontant betaling. Britta fortæller, at hun var nødt til at betale nogen for at handle for sig, da hun året før var immobiliseret i et par måneder på grund af et uheld i en brandert; "Der havde jeg ikke nogen venner mere (...). Så tager de ikke telefonen, så kan de ikke, så har de tyndskid". Relationerne er på nogle måder sårbare, fordi man ikke kan være sikker på, om hjælpen er der, hvis tingene ændrer sig (cf. Bourgois \& Schonberg, 2009; Desmond, 2012).

Selv om netværket i skuret ofte er til hjælp, og der bliver udtrykt omsorg blandt brugerne både gennem ord og handlinger, så er der, som Harald udtrykker det, " bare ikke noget sikkerhedsnet under den omsorg". Man kan ikke være sikker på, at omsorgen er der, når man har brug for den, forklarer han: "Du kan håbe på det. Og man kan nemt blive skuffet". Citaterne illustrer den ambivalens, der relaterer sig til at indgå i de kassérbare relationer (Desmond, 2012): På den ene side er brugerne glade for og afhængige af relationerne for at føle tilhør og for at få hjælp. På den anden side er de meget bevidste om risikoen for svigt, som relationerne indeholder.

"Der er en del sociale koder," fortæller Harald, der mener, at det betyder noget, at skuret ligger i det lokalområde, de fleste af brugerne selv bor i. "Der er en grænse for, hvor hårdt man skal skide i egen rede", konstaterer han. Hvor man på den ene side kan opleve det som pinligt at være en af "dem" fra skuret, er det også noget disciplinerende ved, at der er øjne fra naboer og professionelle fra lokalområdet på skuret. 


\section{Disciplinering og selvdisciplinering}

Skurets egne sociale koder er også med til at forme brugernes adfærd, og noget som - i hvert tilfælde i nogen grad - sætter brugerne i stand til at agere i overensstemmelse med dominerende ideer om "gode" og "sunde" valg både i forhold til almindelig takt og tone, men også i forhold til sundhed. Det skete for eksempel et par gange under feltarbejdet, at mere perifere brugere blev irettesat, hvis de overskred de andre tilstedeværendes grænser. En eftermiddag under feltarbejdet i efteråret 2019 havde Thomas "fået lov" at komme i skuret efter en periode, hvor han ikke havde været velset på grund af sin opførsel. Det "fejrede" Thomas, som var synligt beruset, med at lyse flere af de andre ind i øjnene med en lommelygte. Nogle dage senere plejede Jakob et bidesår i fingeren. Adspurgt fortalte Jakob og Anette i fællesskab, at Thomas havde været der igen og havde siddet og lyst folk ind i hovedet med sin lommelygte. Det var blevet for meget, og efter Anette havde bedt ham lade være, og Thomas ikke var stoppet, havde Jakob taget fat $\mathrm{i}$ ham for korporligt at smide ham ud af skuret. I tumulten havde Thomas bidt Jakob i fingeren. I retur havde han fået et par på hovedet af Jakob. Det var tydeligt, at Thomas ikke var velkommen igen foreløbigt, og at vurderingen blandt de tilstedeværende var, at han selv havde været ude om både udsmidning og afstraffelse. Han havde været på prøve på grund af tidligere opførsel, og da han ikke kunne overholde de sociale spilleregler, blev der reageret.

Lignende historier blev fortalt om andre, der havde overtrådt de uskrevne regler. Flere af historierne indeholdt fysisk afstraffelse - blandt andet af en mand ved navn Freddy, der havde skubbet en af skurets mere sporadiske brugere for "ikke at smile tilbage til ham". Det havde fået Anette til at tage fat i Freddy "så hans underbukser revnede", og han havde sidenhen "fået et blåt øje og en skramme i baghovedet", da en anden, unavngiven person havde haft fat i ham. Nu holdt Freddy sig på sikker afstand af skuret. Eksemplerne på brugernes håndtering af "dårlig" og "usund" opførsel er nok relativt kontante i deres udtryksform, men ikke desto mindre vidner det om, at man i skuret ikke tolerer mobning og voldsom opførsel, samt at man forventer af hinanden, at man skal tage særligt hensyn til de allermest udsatte brugere. Der herskede en bestræbelse på, at man i skuret ville have et socialt inkluderende miljø - måske netop på grund af bevidstheden om, at fællesskabet byggede på kassérbare relationer (Desmond, 2012), som skulle plejes og vedligeholdes for at fungere. Bestræbelserne på at skabe et miljø, hvor der blev reageret på overskridelser af de uskrevne regler, og man i øvrigt bestræbte sig på at behandle andre "ordentligt" og drage omsorg for andre, lykkedes ikke altid, 
men især blandt den faste kerne blev vigtigheden af at man "opførte sig ordentligt" ofte understreget. Fællesskabet var åbent for at andre kom og slog sig ned, men der kunne også hurtigt blive markeret, hvis man trådte udenfor.

Da corona-pandemien ramte Danmark, påvirkede det naturligt nok også interaktionen i skuret. Corona-situationen fyldte meget og blev diskuteret ivrigt. I maj 2020 var der en stols afstand mellem hver af dem, der havde slået sig ned i skuret, og flere havde håndsprit med, som de demonstrativt brugte ind i mellem. Nogle få bar også handsker og gjorde opmærksom på, når de syntes andre kom for tæt på. Det var tydeligt, at situationen blev taget alvorligt, og de tilstedeværende gjorde, hvad de kunne, for at signalere at de levede op til myndighedernes anbefalinger om afstand og hyppig brug af håndsprit. Ligesom skurets brugere tilpassede deres adfærd under corona-nedlukningen, var det også gennemgående, at brugerne generelt gjorde en dyd ud af at hilse pænt på forbipasserende og sende signaler om, at nok sad de og drak øl, men "vi tænker også på andre og hjælper hinanden", som Anette udtrykte det. Selv om de var klar over, at andre kunne se ned på dem og opfatte dem som uansvarlige og selv skyld i de problemer, de havde - også hvis de skulle pådrage sig covid-19 - var det vigtigt for de fleste i skuret at fremstå som mennesker, der kerede sig om andre og godt kunne tage vare på sig selv og tilpasse deres adfærd.

Anette var blandt dem, der ofte italesatte vigtigheden af at drage omsorg for andre og udvise ansvarlighed. Hun kom selv fra en familiebaggrund, hvor alkohol havde fyldt meget, og havde efter eget udsagn første gang stiftet bekendtskab med bajerne, da hendes mor efter hendes konfirmation havde taget hende og hendes storesøster med på beværtning, hvorfra pigerne var blevet sendt hjem, mens moderen brugte konfirmationspengene. Siden havde "øllerne" fyldt meget i hendes liv, men hun fastholdt en stolthed over, at hun havde været i stand til at arbejde en stor del af sit voksenliv. "Hvis man kan gå på druk, kan man også stå op og gå på arbejde næste dag," proklamerede hun. Anette var kendt i skuret for at komme slæbende på bæreposer med varer købt på tilbud eller billigt, fordi de var tæt på eller over sidste salgsdato. Hun handlede både systematisk til Jakob og andre, men også mere sporadisk når hun fandt tilbud på noget, hun vidste andre i skuret godt kunne lide eller manglede. Men det var vigtigt for hende at understrege, at hun også skulle have sin betaling - hvis folk ikke betalte eller var langsomme til det, kom de i hendes sorte bog. Igen er der tale om nogle ret kontante vilkår for hjælp $\mathrm{i}$ fællesskabet, idet Anette nærede en potentiel mistillid i forhold til pålideligheden af de relationer, hun indgik i (cf. Desmond, 2012; Bourgois \& Schonberg, 2009). 
Jakob talte også ofte om "ordentlighed" blandt andet i relation til handel med stoffer. Han havde selv solgt stoffer, da han var yngre, og havde efter eget udsagn "altid behandlet folk ordentligt". Nu hvor han selv ofte var i økonomisk knibe og havde behov for mere og stærkere smertestillende midler, end hans læge ville udskrive til ham, for hans rygsmerter, oplevede han at blive afvist af sin heroinpusher, selv om han "altid betalte til den første". Han fortalte også om, hvordan mange solgte stoffer, de ikke kendte ret meget til, og i doser som aftagerne ikke kunne finde ud af at indtage. En dag på torvet kom en ældre velsoigneret kvinde forbi skuret og ville høre, om Jakob "havde noget". Hun havde smerter, og hendes læge ville ikke udskrive stærke smertestillende piller til hende. Jakob kiggede sig lidt omkring, og fandt et par piller frem gemt i en pakke lommetørklæder. Han knækkede den ene pille over og fik en halvtredser af kvinden, inden han insisterende forklarede hende, at hun skulle tage den halve og vente på den virkede. Hun skulle ikke tage den anden halvdel før dagen efter. Da kvinden var gået igen, fortalte Jakob antropologen, at han ikke troede, kvinden selv ville kunne styre indtaget af piller, hvis hun fik flere - og de var så stærke, at de kunne slå hende ihjel, hvis hun tog flere ad gangen. Derfor ville han ikke sælge hende mere end én. For Jakob var det vigtigt at understrege, at han behandlede sine "kunder" ordentligt - og ikke som han selv oplevede at blive behandlet.

Selvom brugerne i skuret på papiret ligner andre ældre og alderssvækkede, udsatte borgere (Rambøll, 2020; Benjaminsen, 2019; Pedersen, 2018), som generelt træffer "dårlige" sundhedsmæssige valg (cf. Møller \& Merrild, 2019; Blue et al., 2016), fordi de drikker for meget, ryger, tager stoffer, bevæger sig for lidt, kommer for sjældent og for sent til læge osv., er der en tydelig bevidsthed om, hvad det "rigtige" og "ordentlige" sundhedsmæssige er at gøre, og brugerne efterlevede eksempelvis i vid udstrækning også sundhedsstyrelsens guidelines for COVID-19. Endvidere viser eksemplerne, at brugerne i det hele tager går op i og agerer kompetent $i$ forhold til deres egen og deres kammeraters sundhedstilstand og trivsel. Der er ikke tale om en 1:1 udlevelse af sundhedsfremmende råd og anbefalinger (cf. Møller \& Merrild, 2019; Andersen \& Risør, 2014; Broholm-Jørgensen et al., 2019), men brugerne formår i nogen grad at tilpasse disse til den konkrete livssituation, som de befinder sig i og derved minimere nogle af de skavanker og udfordringer, fysiske såvel som mentale, som de døjer med, og som de har vanskeligt ved at få hjælp til i velfærdssystemet (cf. Bjerge et al,. 2019; Social- og Indenrigsministeriet, 2016; Pedersen, 2018; Rambøll 2020). I den forstand fungerer skuret og de relationer, skurets brugere indgår i, som et alternativ til velfærdssystemet. Skuret opfylder brugernes behov og efterspørgsel efter et sted at høre til 
og diskutere stort og småt. Skuret giver adgang til praktisk hjælp, og omsorgen og forpligtigelsen over for fællesskabet medvirker til, at skurets brugere - i hvert fald i de beskrevne tilfælde - agerer mere i overensstemmelse med samfundsmæssigt dominerende forestillinger, om at borgere bør træffe "fornuftige" og "ordentlige" valg - dog fortolket ud fra egne forudsætninger.

\section{Diskussion og konklusion}

I artiklen har vi demonstreret, hvordan udsatte ældre og alderssvækkede rusmiddelbrugeres fællesskab i og omkring 'skuret' er omdrejningspunkt for et vigtigt socialt fællesskab, hvor brugerne drager omsorg for sig selv og hinanden med henblik på at klare sig økonomisk, trivsels- og sundhedsmæssigt. Fællesskabet fungerer som et alternativ til den hjælp, som brugerne i princippet skulle kunne bruge velfærdssystemet til. Hjælpen og omsorgen, som udspringer af fællesskabet, sætter i nogen grad brugerne i stand til at tage vare på deres sundhed og trivsel, og selv om deres livsførelse ikke nødvendigvis er skoleeksemplet på velfærdsstatens "mønsterborgere", så søger de i fællesskab og på egen hånd at minimere omfanget af de skader, som deres livsførelse kunne have medført. Dog er fællesskabet baseret på relationer, som opleves som mere flygtige, mere ambivalente og ad hoc-prægede end de relationer, som kendetegner for eksempel mange familierelationer, og $\mathrm{i}$ den forstand ligner skurets brugere mange andre udsatte borgeres typer af relationer (jf. Bourgois \& Schonberg, 2009; Desmond, 2012; Mortensen, 2019).

Skurets brugere insisterer på at fastholde nogle regler og opføre sig moralsk og sundhedsrelateret "ordentligt" som en måde at operere i gråzonen mellem gademiljøet og det omgivende samfunds forståelse af god opførsel (cf. Bourgois \& Schonberg, 2009). I praksis balancerer de således mellem forskellige moralske ordener og fungerer i to verdener, hvor man på den ene side kan klare sig på gaden og ikke lader sig narre i miljøet og erkender ambivalensen i de relationer, man indgår i, og samtidig også agerer i overensstemmelse med forestillinger om gode eller ordentlige samfundsborgere, der passer på sig selv og deres omverden.

Skal sundheds- og omsorgstilbud gøres mere tilgængelige for ældre og alderssvækkede udsatte borgere som skurets brugere, er der flere parametre, som bør diskuteres. På baggrund af artiklens fund peger vi på to centrale områder: For det første er der brug for en øget forståelse for de måder, hvorpå brugere og system møder hinanden på, og for det andet er der brug for en øget forståelse for 
brugernes frygt for at miste autonomi og selvbestemmelse. Disse hænger i praksis sammen.

I forhold til førstnævnte, peger Professor og læge Morten Sodemann (2020) på, at stigmatisering af specifikke borgergrupper gør, at mange holder sig væk fra sundhedssystemet, og at udfordringen ikke skal findes blandt borgergruppen, men på systemniveau. "Over 90 procent af de interventioner, der er igangsat for at reducere ulighed [i sundhedssystemet], er rettet mod at ændre på patienternes viden, adfærd, holdninger og egenomsorg. Under 10 procent handler om at ændre sygehusvæsnets organisation, forståelse eller omsorg" (Sodemann, 2020; cf. Bjerge et al., 2019). Selvom brugerne i skuret alle var dansktalende, tidligere havde haft tilknytning til arbejdsmarkedet osv., så oplevede de på lige fod med for eksempel indvandrergrupper at blive mødt af manglende forståelse i de fleste interaktioner med velfærdssystemet. Netop oplevelsen af manglende forståelse af deres individuelle livssituation, historie og behov var kendetegnende, og blev beskrevet som noget, der afholdt dem fra at indgå oftere og mere positivt i samarbejder med systemernes professionelle (cf. Møller \& Merrild, 2019; Blue et al., 2016; Andersen \& Risør, 2014; Broholm-Jørgensen et al., 2019). Samtidig opleves kontaktfladerne til sundhedssystemet som bureaukratiske og fyldt med krav, som stiller barrierer op i forhold til at søge hjælp - for eksempel tidsbestilling og visitation. Der er mange social- og sundhedsprofessionelle, der gør et stort stykke arbejde for at imødekomme brugernes behov og ønsker (cf. Bjerge et al., 2019), men de organisatoriske rammer er ofte ikke tilstrækkelige. For eksempel har en social- og sundhedsassistent $\mathrm{i}$ hjemmeplejen ofte ikke tid, overskud eller er uddannelsesmæssigt rustet til at komme ind på livet af en borger, der er rusmiddelbruger og har komplekse problemstillinger.

Det er ligeledes helt centralt i det social- og sundhedsprofessionelle arbejde med ældre, udsatte borgere at tage afsæt $\mathrm{i}$ borgerens selvstændighed og autonomi, der er nødvendig for at kunne klare sig i et hårdt miljø (jf. Bourgois \& Schonberg, 2009; Desmond, 2012). I lighed med de ældre rusmiddelbrugere i skuret beskriver Jon Dag Rasmussen (2019) i et studie af udsatte ældre og mobilitet i København, hvordan ældre, der indlægges eller på anden måde mister deres mobilitet, også på en måde "dør" socialt, når de ikke længere er i stand til at passe deres sociale netværk og relationer til bestemte steder og miljøer i længere perioder. Denne sociale "død" knyttes ofte til den fysiske død (ibid.). Er man først "død" socialt er erfaringen, at den fysiske død hurtigt følger efter. At blive indrulleret i lange, plejekrævende forløb kommer således til at symbolisere et tab af mobilitet og derved socialt liv. Når man har behov for omfattende sundhedsmæssig pleje eller 
omsorg, er det et symptom på, at enden nærmer sig (ibid). Det er således ikke nødvendigvis plejen eller omsorgen i sig selv, der opfattes som problematisk af borgere som Jakob, Anette, og alle de andre brugere af skuret, men det at omsorgsbehovet opstår, når den fysiske tilstand forværres og mobiliteten begrænses. Det er endvidere vigtigt at anerkende angsten for at miste selvbestemmelse og kontakten til det sociale fællesskab. Oplevelsen af at have en eller anden form for selvbestemmelse og kontrol over deres egen tilværelse er vigtig også for udsatte borgere, på trods af at de også selv kan erkende, at den er mere kaotisk end de fleste andre menneskers. Dét at have friheden til at vælge til og fra og selv være med til at definere omfanget og tidspunktet for sundhedsfaglig hjælp eller omsorg synes at være centralt for skurets brugere. I forlængelse heraf er det også vigtigt at have øje for, at de fællesskaber, som er centrale for at holde dem oppe i hverdagen, er specifikt situerede til for eksempel skuret i Kildebjerg og ikke umiddelbart er flytbare til andre lokationer - en placering på plejehjem kunne resultere i et tab af det sociale netværk og dermed en "social død" (Rasmussen, 2019) for pågældende bruger, hvorfor der synes at være særlig meget på spil for brugerne af skuret.

\section{Noter}

i Definitionen af udsatte tager afsæt i den definition af social udsathed, som anvendes af Rådet for Socialt Udsatte i SUSY UDSAT-sundhedsprofilerne (Ahlmark et al 2017) og anvendes i rapporten Kortlægning af viden om grupper af ældre udsatte borgere med særlige behov og er udviklet af Rambøll i samarbejde med Sundhedsstyrelsen og to eksperter (Christine Swane og Torben Larsen): Ældre over 50 år, som lever i social udsathed, karakteriseret ved, at de lever med/i en eller flere af fire følgende forhold: • Alkoholmisbrug • Stofmisbrug • Hjemløshed • Sindslidelse(r) (Rambøll/Sundhedsstyrelsen 2020).

ii Vi refererer til "velfærdssystemet" som en samlet betegnelse for den type systemiske og offentlige indsatser, som tilbydes borgere i den danske velfærdsstat. Det vil sige sundheds- og omsorgssystemet (fx egen læge eller hjemmepleje) samt sociale, kommunale indsatser (fx støtte-kontakt person eller afklaring af førtidspension).

iii Flere af skurets brugere refererer til det som et "drikkeskur" - et udtryk der også benyttes i forhold til skure på andre lokationer i Aarhus.

iv Skurets historie er stykket sammen af interviews med brugere og en professionel, som har arbejdet i området siden 1990'erne.

v Som den boligsociale leder udtrykte det i et interview.

${ }^{v i}$ Morfinpræparat mod stærke smerter.

vii Jeg introducerede mig selv som forsker ved Center for Rusmiddelforskning, og fortalte at jeg gerne ville blive klogere på, hvordan skurets brugere oplevede at sidde i skuret. Siden har jeg fortalt, at jeg gerne vil undersøge skurets brugeres møder med sund- 
hedssystemet. Skurets brugere har også fået en tidligere artikel til gennemlæsning efter udgivelse (Bach 2020), så de kunne se og kommentere på, hvordan de var fremstillet.

\section{Referencer}

Ahlmark, N.; Sørensen, I.; Davidsen, M. \& Ekholm, O. (2018). SUSY UDSAT 2017. Sundhedsprofil for socialt udsatte $i$ Danmark. Statens Institut for Folkesundhed og Rådet for Socialt Udsatte

Andersen, D. \& T. Bengtsson. (2019). Rettidighed og synkronisering af indsatser I komplekse ungesager. In Bjerge, B. \& E. Houborg (eds). Rusmiddelbrugere i krydsfeltet mellem sektorer og fagligheder, 45-64. Aarhus, Aarhus University Press

Andersen, R. S. \& Risør, M. B. (2014). The importance of contextualization: Anthropological reflections on descriptive analysis, its limitations and implications. Anthropology and Medicine, 21, 345-356

Benjaminsen, L. (2019). Hjemløshed i Danmark 2019: National kortlægning. Det nationale forsknings- og analysecenter for velfærd

Bjerge, B, Christensen, L. \& J. Oute. (2020). Complex cases: Complex representations of problems. International Journal of Drug Policy. Available online

Bjerge, B.; Oute, J.; Christensen, L. \& M. Nygaard-Christensen. (2019). Om at "strikke" et social tilbud sammen til borgere med komplekse problemstillinger. In Bjerge, B. \& E. Houborg (eds). Rusmiddelbrugere i krydsfeltet mellem sektorer og fagligheder, 19-44. Aarhus, Aarhus University Press

Bjerge, B. \& E. Houborg (2019). Introduktion. In Bjerge, B. \& E. Houborg (eds). Rusmiddelbrugere i krydsfeltet mellem sektorer og fagligheder. Aarhus, Aarhus University Press, 9-15

Blue, S.; Shove, E.; Carmona, C. \& Kelly, M. P. (2016). Theories of practice and public health: understanding (un)- healthy practices. Critical Public Health, 26, 36-50

Bourgois, P. \& Schonberg, J. (2009). Righteous Dopefiend. University of California Press, Berkeley and Los Angeles

Brandt, P. et al. (2009). Udsat for forståelse. Rådet for Socialt Udsatte

Broholm-Jørgensen, M; Kamstrup-Larsen, N.; Guassora, A. D.; Reventlow, S.; Dalton, O. A. \& Tjørnhøj-Thomsen, T. (2019). British Journal for Person Centered Healthcare, 7, 2, 334-343

Desmond, M. (2012). Disposable Ties and the Urban Poor. American Journal of Sociology, 117:5, 1295-1335

Frederiksen, K. S.; Pedersen, M. U. \& S. Jones. (2019). Hvordan hjælpes unge med psykiske problemer bedst i rusmiddelbehandlingen? In Bjerge, B. \& E. Houborg (eds). Rusmiddelbrugere i krydsfeltet mellem sektorer og fagligheder, 159-182. Aarhus, Aarhus University Press

Larsen, J. L. \& K. S. Johansen. (2019). Dobbetdiagnose: En ubekvem betegnelse i det tværsektorielle arbejde? In Bjerge, B. \& E. Houborg (eds). Rusmiddelbrugere i krydsfeltet mellem sektorer og fagligheder, 137-158. Aarhus, Aarhus University Press

Mortensen, E. (2019). Being Care-ful Among Friends: The Ambiguities of Friendship in Exile. Etnofoor 31:1, 29-46. 
Møller, A. \& C. Merrild. (2019). Exploring targeted preventive health cheks in a socially disadvantaged neighborhood in Denmark. Health Promotion International, e-pub ahead of print

Møller, A. F. \& A. Nørlyk. (2017). Ældres patienters oplevelse af selvbestemmelse, når de modtager sygepleje i eget hjem: en fænomenologisk-hermeneutisk analyse undersøgelse. Klinisk Sygepleje 31: 4, 257-272

Pedersen, P. V. (2009). Dårligt liv, dårligt helbred: Socialt udsattes oplevelse af eget liv og sundhed. Rådet for Socialt Udsatte

Pedersen, P. V. (2018). Socialt udsattes møde med sundhedsvæsnet. Statens Institut for Folkesundhed. København: Syddansk Universitet.

Rambøll (2020). Kortlægning af viden om grupper af udsatte ældre borgere med særlige behov. Rapport, Sundhedsstyrelsen

Rasmussen, J. D. (2019). Ældre på samfundets overflade. Frydenlund Academic

Sodemann, M. (2020). Skal socialt udsatte eller velstillede vælgere forrest i køen til sundhedsvæsenet?. Tidsskrift for Dansk Sundhedsvæsen. https://dssnet.dk/artikler/debat/ morten-sodemann-socialt-udsatte-eller-velstillede-vaelgere/

Social- og Indenrigsministeriet. (2016). Socialpolitisk redegørelse.

Sundhedsstyrelsen (2012). Et sundt liv for udsatte borgere: Erfaringer fra 13 indsatser, der har sat fokus på sundhed for misbrugere, alkoholikere, hjemløse og psykisk syge mennesker. https:// www.sst.dk/-/media/Udgivelser/2012/Publ2012/SURA/SocialtUdsatte/Et-sundere-livfor-udsatte-borgere.ashx

Thylstrup, B. \& Hesse, M. At arbejde med problematisk brug af rusmidler er at arbejde med psykiske vanskeligheder. In Bjerge, B. \& E. Houborg (eds). Rusmiddelbrugere i krydsfeltet mellem sektorer og fagligheder, 183-205. Aarhus, Aarhus University Press 